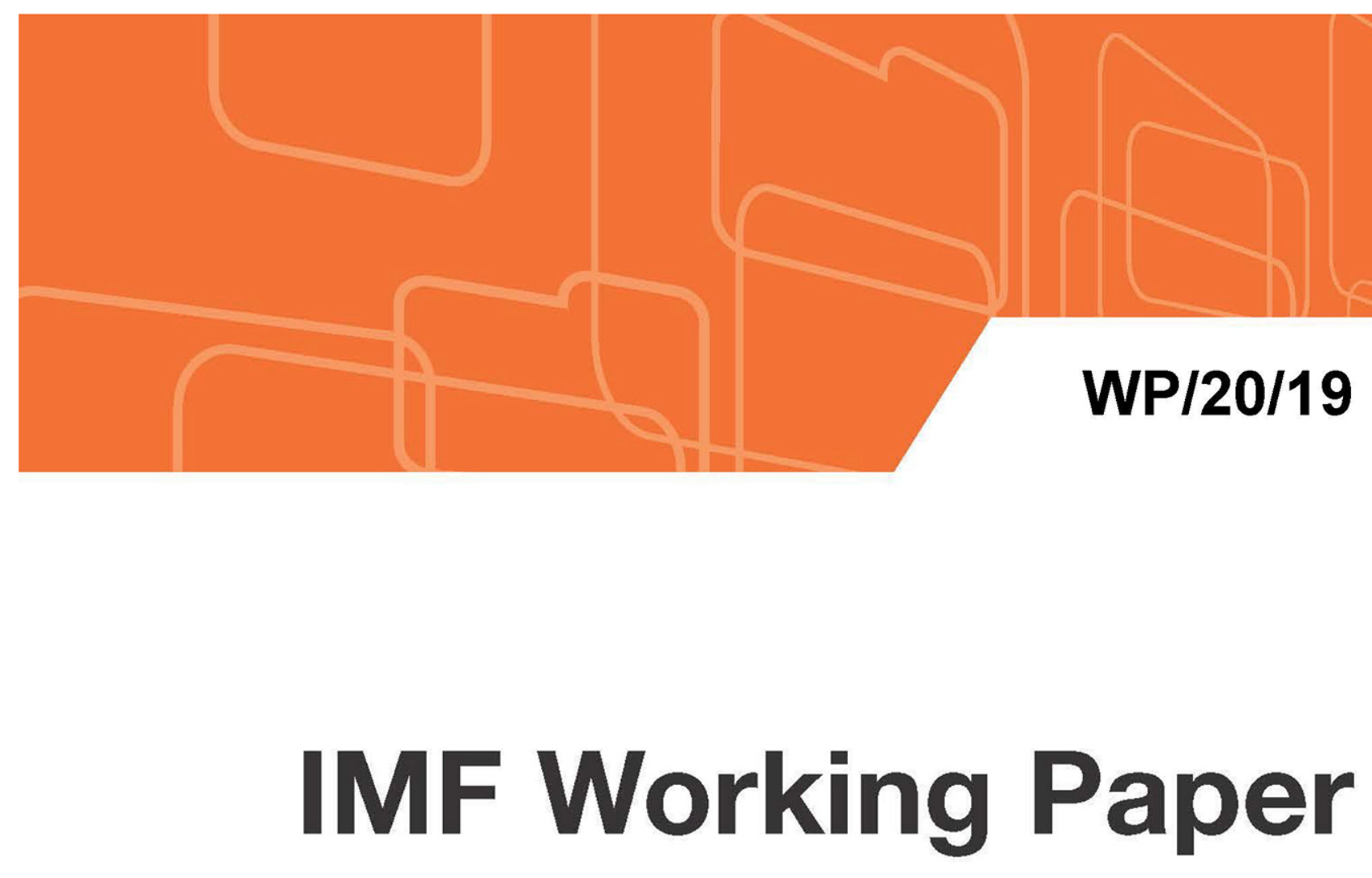

\title{
Labor Market Dynamics, Informality, and Regulations in Latin America
}

by Antonio David, Samuel Pienknagura, and Jorge Roldos 


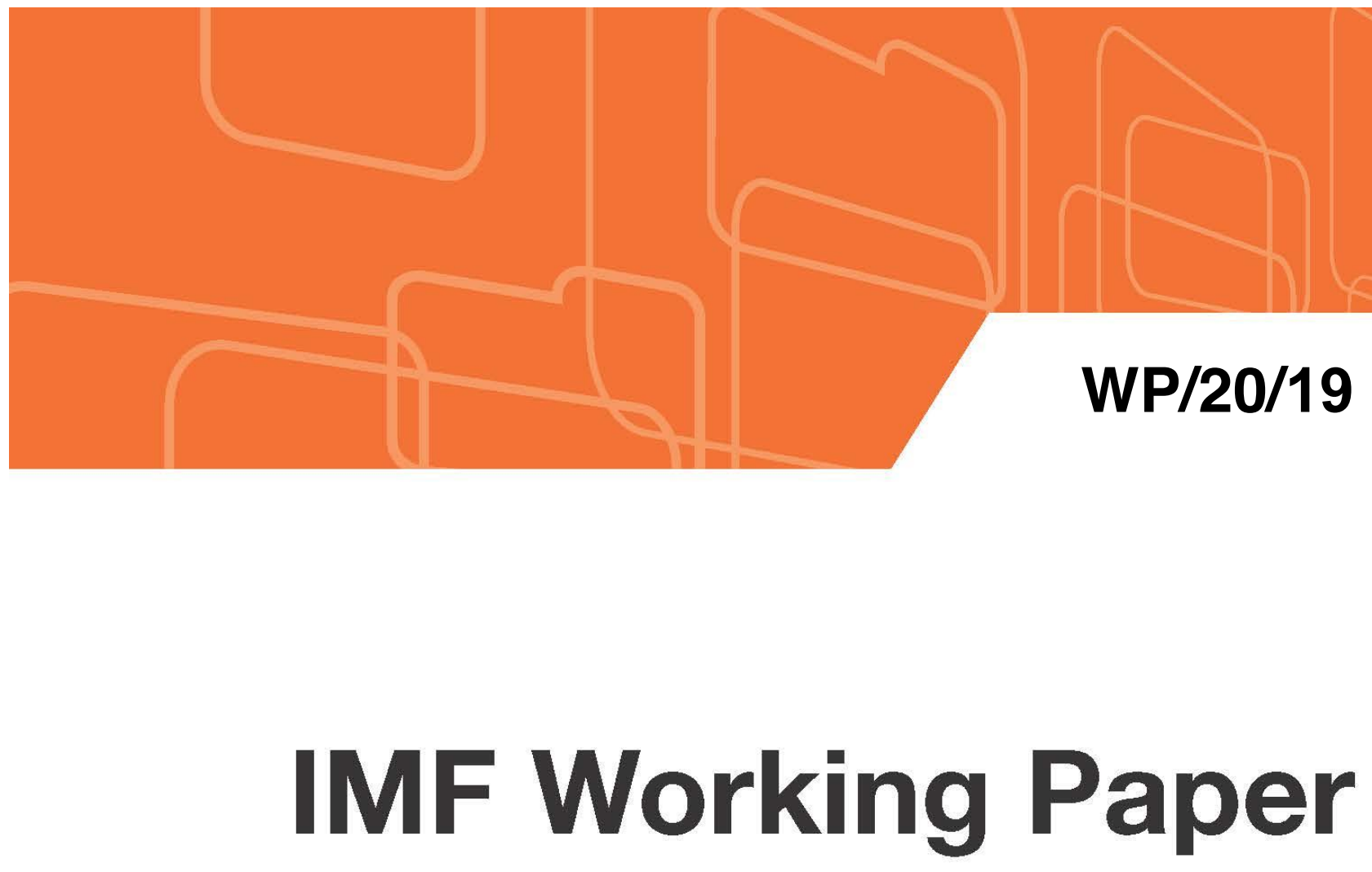

Labor Market Dynamics, Informality, and Regulations in Latin America

by Antonio David, Samuel Pienknagura, and Jorge Roldos

I N T E R N A T I O N A L M O N E T A R Y F U N D 


\title{
IMF Working Paper
}

Western Hemisphere Department

\section{Labor Market Dynamics, Informality, and Regulations in Latin America}

\author{
Prepared by Antonio David, Samuel Pienknagura, and Jorge Roldos*
}

Authorized for distribution by Jorge Roldos

January 2020

\begin{abstract}
IMF Working Papers describe research in progress by the author(s) and are published to elicit comments and to encourage debate. The views expressed in IMF Working Papers are those of the author(s) and do not necessarily represent the views of the IMF, its Executive Board, or IMF management.
\end{abstract}

\begin{abstract}
Labor markets in Latin America and the Caribbean (LAC) are characterized by high levels of informality and relatively rigid regulation. This paper shows that these two features are related and together make the speed of adjustment of employment to shocks slower, especially when regulations are tightly enforced. Evidence suggests that strict labor market regulations also have an adverse effect on medium-term growth. While both regulations on prices (minimum wages) and quantities (employment protection) decrease the speed of adjustment to shocks, they appear to be binding in different phases of the cycle - the former affects mostly the (net) job creation margin and the latter the (net) job destruction margin. The results also highlight possible interactions between labor market regulations and the effectiveness of macro-stabilization tools - including exchange rate depreciation.
\end{abstract}

JEL Classification Numbers: E2, E32, E61, J3, J4

Keywords: Labor Market Adjustments, Labor Market Regulations, Informality, Latin America Author's E-Mail Address: adavid@,imf.org,spienknagura@,imf.org,jroldos@,imf.org

* Genevieve Lindow and Dan Pan provided excellent research assistance. The authors thank Jaime Guajardo, Camila Perez Marulanda, and Ippei Shibata for their valuable comments. 


\section{INTRODUCTION}

Labor markets in Latin America and the Caribbean (LAC) are characterized by high levels of informality, a feature that is attributed, among other things, to relatively strict labor market regulations. Informality declined in LAC labor markets but continues to be a feature of roughly half the level of employment in the region (Kugler, 2019 and World Bank, 2019). Evidence suggests that informality is driven by income per capita and education of the labor force (La Porta and Shleifer, 2014), but also by strict labor regulations and taxation (Finkelstein Shapiro, 2015, David, Lambert and Toscani, 2019). Indeed, labor markets in LAC exhibit regulatory rigidities in several key dimensions. Redundancy costs, measured in number of weeks of salaries, are higher than in Advanced Economies (AEs) or other Emerging Market and Developing Economies (EMDEs) (see Lambert and Toscani, 2018), dismissal of even one worker often requires third-part approval, and permanent contracts are mandatory for permanent tasks in many countries. Also, the ratio of the minimum wage to value added, a measure of how binding minimum wages are, is higher in LAC compared to AEs and in Central American countries is higher than the average EMDE (IMF 2019a).

This paper examines the cyclical properties of informality, reassesses the link between labor market regulations and informality, and provides new evidence on how both these features shape the cyclical dynamics of labor markets in LAC. Moreover, the interaction between labor market features and macroeconomic stabilization tools such as exchange rate flexibility, and the relationship between the speed adjustment to shocks and productivity growth, are also reassessed using a dataset of sector-level employment for a large set of countries. This is done in a context where the labor market gains achieved during the commodity price super-cycle appear to have stalled amid the region's flagging growth and many countries are turning towards structural reforms in search of reigniting labor market dynamism. While the paper focuses mostly on LAC countries, the empirical analysis presented typically includes data from a wider set of countries, which can be particularly useful for benchmarking purposes.

The findings provide new evidence of the counter-cyclical nature of informality. Informality rises when GDP growth is low and decreases as GDP growth accelerates throughout the LAC region. This is consistent with evidence documented in past studies (see Loayza and Rigolini, 2011). However, taking advantage of the heterogeneous panel data approach used in parts of the paper, the results show large differences across LAC. The strong cyclical response of informality is associated to the findings of David, Lambert and Toscani (2019), who show that the elasticity of unemployment to changes in GDP growth, the Okun coefficient, is lower in countries with higher levels of informality. That finding, together with the counter-cyclical nature of informality documented in this paper, show that the informal sector acts as a buffer to mitigate the labor market impact of shocks to GDP growth.

The paper also shows that informality is positively associated with stringent labor market regulations, especially when these regulations are strongly enforced. Informality rates increase as both employment protection laws (EPLs) become more stringent and when the ratio between minimum wages and labor productivity increases. Moreover, the effects of regulations on informality rates are larger in countries with high levels of government enforcement. This is evidence that de facto labor market regulations are more important in determining labor market outcomes than de jure regulations, a point made by Caballero et al. (2013). 
Finally, the paper shows that high levels of informality as well as stringent regulations affecting quantities (EPLs) and prices (minimum wages) slow the adjustment of employment following shocks and hampers medium-term growth, especially when regulations are binding. However, evidence suggests that these two types of regulations have an asymmetric effect on employment depending on the phase of the business-cycle - regulations on quantities appear to affect the (net) job destruction margin while regulations on prices affect the (net) creation margin. Moreover, the interaction between labor regulations and macro-stabilization tools also depends on the type of regulation. Strict EPLs lower the benefits of exchange rate flexibility as a stabilization tool, but this link is not statistically significant. In contrast, the stabilization benefits of a flexible exchange rate are larger when minimum wages are more binding.

This paper is related to a large literature studying the cyclical properties of labor market outcomes and its determinants. It follows closely Caballero et al. (2013), who study the impact of de facto employment protection on employment adjustments, updates their results to a larger sample and extends it to other labor market regulations and macroeconomic tools. Finkelstein Shapiro (2014) studies the link between informality and the speed of adjustment of an economy towards its steady state output level and finds that higher informality, measured as own account workers and business owners with less than 5 employees as a share of the working-age population, increases the speed of adjustment to shocks in the context of a dynamic model with capital and labor market frictions. The evidence in this paper suggest that in addition to the mechanisms in Finkelstein Shapiro (2014), other opposing forces may be at play when considering interactions between informality and employment dynamics. In particular, this paper highlights the importance of thinking of informality beyond self-employment, as suggested by Ulyssea (2018).

In addition, the evidence in this paper adds to the results in Loayza and Rigolini (2011) by highlighting cross-country differences in the elasticity of informality to changes in GDP growth. Finkelstein Shapiro (2015) documents the link between informality and labor market regulations, and this paper extends his results by distinguishing between the impact of de jure and de facto labor market regulations. Gali and Monacelli (2016) highlight the potential interactions between the benefits of exchange rate flexibility and wage flexibility in the context of a DSGE model. This paper confirms empirically their results by showing how exchange rate flexibility increases the speed of adjustment to shocks especially when minimum wages are high.

The rest of this paper is organized as follows. Section II briefly describes the data used in the analysis and the methodologies employed in the paper. Section III studies the cyclical properties of informality and the link between informality and labor market regulations. Section IV studies the impact of informality and labor market regulations on employment dynamics. Section V analyzes the growth effects of labor market regulations, while section VI concludes.

\section{Data And Methodological Approach}

The paper uses a combination aggregate labor market data and sectoral data to study the cyclical properties of informality and employment. For a detailed description of variables and sources of data used in the analysis see Appendix A. Cross-country data on informality comes from the International Labor Organization (ILO) with focus on the share of informal employment in total non-agricultural employment. The informal employment status of the job is determined by, among other criteria, the informal sector nature of the enterprise (ILO, 2018). Informal firms are 
unregistered and/or small-scale private unincorporated enterprises. Time series data on informality for LAC countries comes from the IDB's SIMS database, which uses pensions contributions as the criterion for formality.

Data for broad sectoral and aggregate employment come from the World Bank's World Development Indicators (WDI). The sample used includes data from 1990 until 2017 for all countries with a population over one million people.

The job security index used in the paper is constructed following Botero et al. 2004. The index combines information from the World Bank's Doing Business (DB) indicators and is the sum of three variables each of which is normalized to take a value between 0 and 1 . The variables are: time to notify dismissals, approval of dismissals by a third part, and severance payments. The minimum wage variable is the ratio between the national minimum wage and GDP per worker (labor productivity). The data has broad country coverage but is limited in the time-series dimension.

The government effectiveness estimates are taken from the latest Kaufmann, Kraay, and Mastruzzi (2010) governance indicators dataset. The authors construct estimates by using information from a large number of surveys and databases. The variable "High government effectiveness" is a dummy variable taking value one if a country has a government effectiveness estimate in 1996 above the global median in that year.

The index of exchange rate flexibility comes from Ilzetzki, Reinhart and Rogoff (IRR) (2019) which categorizes exchange rate regimes into six groups. The empirical exercise in this paper codes the index as dummy variable taking value 1 (flexible) if the IRR index takes values 3 and 4 , and zero (non-flexible) if it takes values 1 and 2.

Finally, the main data source for the sectoral analysis is the 3-digit United Nations Industrial Development Organization (UNIDO) Industrial Statistics (INDSTAT) database, Rev. 3. The dataset contains output, employment, wages and capital data for 28 manufacturing sectors for a large set of countries. Parts of the paper complements the data with two additional sources. Employment, output, and wage data for construction and service sectors for European countries comes from the STAN dataset, which contains information for the 2005-17 period. Employment and value-added data for construction and service sectors for non-European countries comes from the 10-sector database compiled by Timmer, de Vries and de Vries (2015), which contains information for 40 countries for the period between 2000 and 2010.

The paper uses a variety of methodological approaches to tackle the main questions of interest as explained in detail in later sections. In order to study the cyclical behavior of informality and the adjustment of employment to long-run equilibrium levels, the paper uses heterogeneous panel regression models. Subsequently, we follow the methodology proposed by Caballero et al. (2013) to assess the impact of labor market regulations and their interactions with macro policies on the speed of adjustment of employment to equilibrium. Finally, the paper studies the effects of labor market regulations on growth following a difference-in-difference approach similar to the one proposed by Rajan and Zingales (1998). 


\section{The CyClical Properties of Informality and its LinK to Labor Market REGULATIONS}

In order to study the cyclical behavior of informality, the paper uses a heterogeneous panel regressions approach. This approach allows slope coefficients to vary across countries and deals with possible cross-sectional dependency through the inclusion of common factors in the estimation. The sample includes both emerging and advanced economies. The empirical specification can be summarized in equation 1 for $i=1, \ldots, N$ countries; and $t=1, \ldots, T$ time periods.

$$
\begin{aligned}
& \Delta Z_{i, t}=\beta_{i} \Delta y_{i, t}+\gamma_{i} \Delta y_{i, t-1}+\theta_{i} \Delta y_{i, t-2}+\vartheta_{i, t} \\
& \vartheta_{i, t}=\alpha_{i}+\sum_{m=1}^{p} \lambda_{i, m} f_{m, t}+\varepsilon_{i, t}
\end{aligned}
$$

where $\Delta Z$ is the change in the informality rate (the ratio of informal to total employment) between periods $t-1$ and $t, \Delta y_{i, t}$ is the change in the log of output (real GDP) between periods $t-1$ and $t, \alpha_{i}$ are country-specific fixed-effects capturing country characteristics that do not change over time; and $f_{m, t}$ are common factors that affect all countries and change over time. These common factors are not directly observable and their factor loadings $\left(\lambda_{i}\right)$ can be country-specific. One reason why accounting for such factors may be important is the possibility that for example, technological changes or movements in global financial conditions, which are common across countries, could affect the relationship between unemployment and output. $\varepsilon_{i t}$ is the error term, which is assumed to be white noise.

Standard panel estimators usually treat the slope coefficients $(\beta, \gamma, \theta)$ as homogeneous across countries. In addition, estimators traditionally used in panel data analysis require the assumption of cross-sectional independence across panel members. In the presence of cross-sectionally correlated error terms, these methods do not produce consistent estimates of the parameters of interest and can lead to incorrect inference (Kapetanios, Pesaran and Yamagata, 2011). In order to address these potential problems, we use the common correlated effects (CCE) estimator proposed by Pesaran (2006). This estimator uses cross-sectional averages of the dependent and independent variables as proxies for unobserved common factors in the regressions.

Informality, defined as the share of active workers contributing to social security, exhibits a clear countercyclical behavior across the sample of LAC countries. Table 1 presents the results for specifications using standard panel models with homogeneous coefficients and country and time fixed effects (column 1) as well as estimates obtained using the CCE estimator and including lags of GDP growth. The estimates suggest that for every additional percentage point of GDP growth, the informality rate falls by up to 0.3 percentage points, although fixed-effects estimates are somewhat smaller. These results are consistent with some of the findings in the literature (Loayza and Rigolini, 2011) and the simple decomposition exercise presented in IMF (2019a). 
Table 1. Responsiveness of Informality to Output Fluctuations in LAC

\begin{tabular}{lcccc}
\hline & $(1)$ & $(2)$ & $(3)$ & $(4)$ \\
& Fixed Effects & CCE & CCE & CCE \\
\cline { 2 - 5 } & $\Delta$ Informality & $\Delta$ Informality & $\Delta$ Informality & $\Delta$ Informality \\
\hline \multirow{3}{*}{$\mathrm{GDP}_{t}$} & $-0.174^{\star * *}$ & $-0.209^{* * *}$ & $-0.266^{\star * *}$ & $-0.261^{\star * *}$ \\
& $(0.0501)$ & $(0.0543)$ & $(0.0743)$ & $(0.0757)$ \\
$\Delta \mathrm{GDP}_{t-1}$ & & & $-0.0607^{*}$ & -0.0553 \\
& & & $(0.0325)$ & $0.0419)$ \\
$\Delta \mathrm{GDP}_{t-2}$ & & & & 0.00315 \\
& & & & $0.0547)$ \\
Constant & $1.007^{* * *}$ & 0.178 & 0.283 & 0.215 \\
& $(0.284)$ & $(0.247)$ & $(0.388)$ & $(0.587)$ \\
Observations & & & & \\
Countries & 356 & 356 & 356 & 356 \\
\hline
\end{tabular}

Source: Authors' calculations.

Note: Standard errors in parentheses. CCE $=$ Common Correlated Effects Estimation.

${ }^{* * *} p<0.01,{ }^{* *} p<0.05,{ }^{*} p<0.1$.

Figure 1 illustrates the heterogeneity of estimated coefficients across sub-regions and countries. Informality rates tend to vary more with the cycle in Central American countries as well as in Colombia and Brazil. The cases of Chile, Argentina and Peru are noteworthy, as informality does not seem to vary much with the cycle, in contrast to other countries in the region.

Figure 1. Informality's Responsiveness to GDP Changes in LAC

(Average country coefficient)

1. By Country Groups

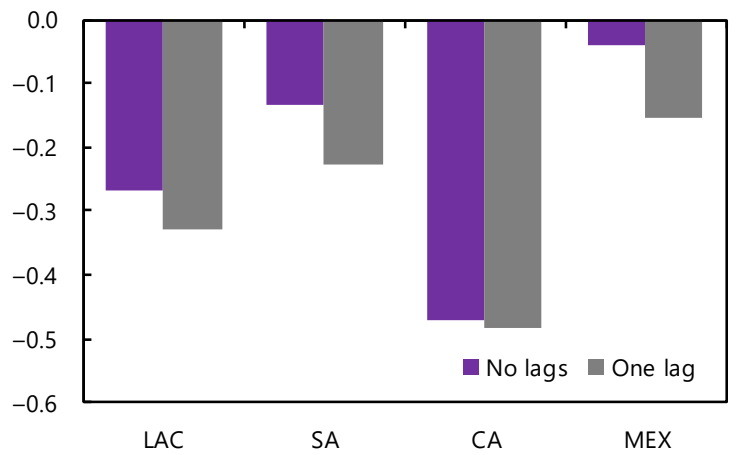

2. Selected LAC Economies

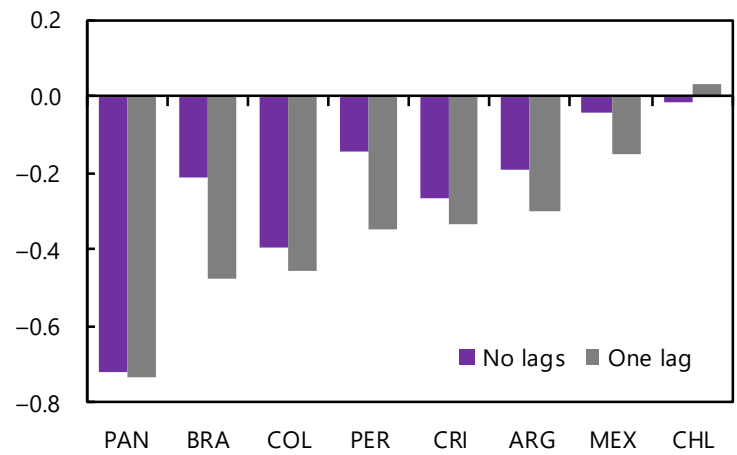

Source: Authors' calculations using data from Inter-American Development Bank, Labor Markets and Social Security Information System (SIMS). Note: Data labels use International Organization for Standardization (ISO) country codes. CA = Central America; LAC = Latin America and the Caribbean.; SA = South America.

In order to assess the robustness of the results to alternative definitions of informality, we reestimate the regressions using the share of self-employed workers (from the World Bank's Word Development Indicators database) as the dependent variable (Table 2). One advantage of using this alternative measure of informality is that it is available for a wider set of countries, which encompasses other regions and income groups.

The countercyclicality of informality is broadly confirmed across the different specifications, albeit estimated coefficients are smaller in absolute value than the ones reported in Table 1, pointing to a smaller sensitivity of this measure to output changes. Nonetheless, the share of selfemployed workers seems to vary more with the cycle in LAC countries when compared to the full set of countries. 
Table 2. Responsiveness of Informality to Output Fluctuations: Alternative Definitions

\begin{tabular}{|c|c|c|c|c|c|c|}
\hline & $\begin{array}{c}\text { (1) } \\
\text { Fixed Effects } \\
\text { All Countries }\end{array}$ & $\begin{array}{c}\text { (2) } \\
\text { Fixed Effects } \\
\text { LAC Only }\end{array}$ & $\begin{array}{c}\text { (3) } \\
\text { CCE } \\
\text { All Countries } \\
\end{array}$ & $\begin{array}{c}\text { (4) } \\
\text { CCE } \\
\text { LAC Only }\end{array}$ & $\begin{array}{c}\text { (5) } \\
\text { CCE } \\
\text { All Countries } \\
\end{array}$ & $\begin{array}{c}\text { (6) } \\
\text { CCE } \\
\text { LAC Only }\end{array}$ \\
\hline & $\Delta$ Self-employed & $\Delta$ Self-employed & $\Delta$ Self-employed & $\Delta$ Self-employed & $\Delta$ Self-employed & $\Delta$ Self-employed \\
\hline$\Delta \mathrm{GDP}_{t}$ & $\begin{array}{c}-0.0227^{\star \star \star} \\
(0.00662)\end{array}$ & $\begin{array}{c}-0.0596^{\star \star \star} \\
(0.0115)\end{array}$ & $\begin{array}{c}-0.0427^{* * *} \\
(0.00671)\end{array}$ & $\begin{array}{c}-0.0597^{* * *} \\
(0.0229)\end{array}$ & $\begin{array}{c}-0.0416^{* * *} \\
(0.00800)\end{array}$ & $\begin{array}{c}-0.0740^{* * *} \\
(0.0247)\end{array}$ \\
\hline$\Delta \mathrm{GDP}_{t-1}$ & & & & & $\begin{array}{l}-0.00671 \\
(0.00714)\end{array}$ & $\begin{array}{c}0.0424 \\
(0.0290)\end{array}$ \\
\hline Constant & $\begin{array}{l}-0.0391 \\
(0.0569)\end{array}$ & $\begin{array}{l}0.517^{\star *} \\
(0.225)\end{array}$ & $\begin{array}{c}0.0241 \\
(0.0394)\end{array}$ & $\begin{array}{l}-0.0284 \\
(0.154)\end{array}$ & $\begin{array}{c}0.0261 \\
(0.0472)\end{array}$ & $\begin{array}{l}-0.0782 \\
(0.165)\end{array}$ \\
\hline Observations & 3,651 & 546 & 3,651 & 546 & 3,633 & 546 \\
\hline Countries & 142 & 21 & 142 & 21 & 142 & 21 \\
\hline
\end{tabular}

Source: Authors' calculations.

Note: Standard errors in parentheses. CCE $=$ Common Correlated Effects Estimation.

${ }^{* * *} p<0.01,{ }^{* *} p<0.05,{ }^{*} p<0.1$.

Labor market regulations and taxes are important determinants of the level of informality. David, Lambert, and Toscani (2019) study this issue in a multivariate regression setting that controls for the level of real GDP per capita and the level of education, variables that are deemed to be important determinants of informality in the literature, as well as other indicators of labor market institutions. These authors find that redundancy costs and a variable capturing whether a thirdparty approval is required to dismiss workers are significantly correlated with informality levels.

Figure 2 presents for a broad set of countries the links (from a cross-country perspective) between informality levels measured as the ratio of informal employment over total nonagricultural employment and two indicators of labor market institutions, namely: severance payments (in weeks of salary) and the ratio of the minimum wage to value added per worker.

Figure 2. Informality and Labor Market Characteristics

1. Informal Employment versus Minimum Wage Ratio

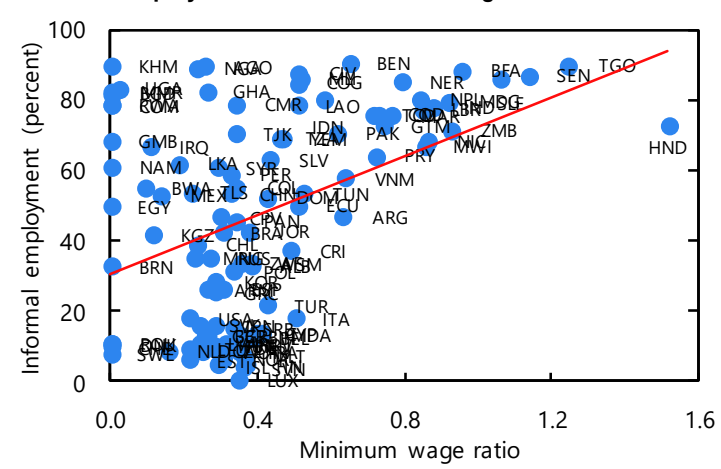

2. Informal Employment versus Redundancy Costs

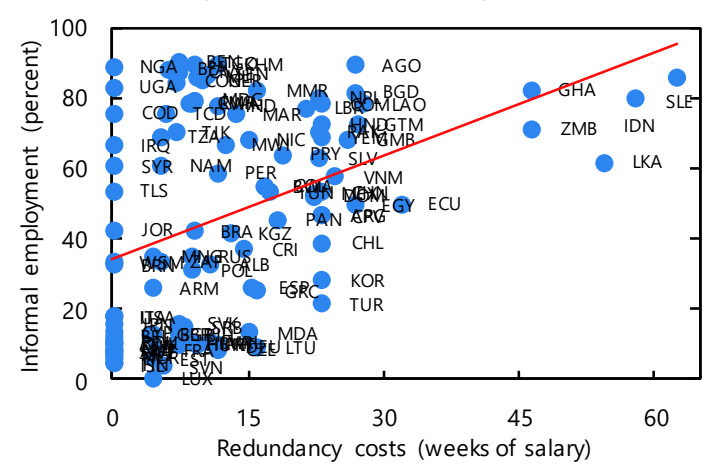

Source: Authors' calculations based on data from World Bank, Doing Business Indicators database. Note: Data labels use International Organization for Standardization (ISO) country codes.

Informality is also affected by the extent to which labor market regulations are enforced in practice. Put simply, similar (stringent) labor market regulations may be less binding in countries with weak government enforcement than in countries with strong enforcement. To explore the impact of the strength of a government's enforcement capacity on informality, the paper follows a similar approach to Caballero et al. (2013), who distinguish between de jure and de facto labor market regulations by interacting regulations with a proxy of government enforcement. The 
exercise studies the effects of regulations affecting job security and minimum wages. The results confirm the positive correlation between regulations that increase job security and the minimum wage with informality rates (Table 3, Columns 1-5), especially when these regulations are more strictly enforced. ${ }^{1}$ To be sure, the statistical significance of the point estimates is reduced once GDP per capita, a common correlate of informality, is included (Table 3, Columns 6-10). Nevertheless, the results still support the view that regulation is linked to informality.

Table 3. Informality and de facto Labor Market Regulations

\begin{tabular}{|c|c|c|c|c|c|c|c|c|c|c|}
\hline & $(1)$ & $(2)$ & (3) & $(4)$ & $(5)$ & (6) & $(7)$ & $(8)$ & (9) & $(10)$ \\
\hline Job security & $\begin{array}{l}0.137^{* * *} \\
(0.0324)\end{array}$ & & $\begin{array}{l}0.121^{\star \star \star} \\
(0.0292)\end{array}$ & $\begin{array}{c}0.0258 \\
(0.0341)\end{array}$ & & $\begin{array}{c}0.0588^{* * *} \\
(0.0178)\end{array}$ & & $\begin{array}{c}0.0589^{* * *} \\
(0.0176)\end{array}$ & $\begin{array}{c}0.0429^{\star} \\
(0.0246)\end{array}$ & \\
\hline Job security * Government effectiveness & & & & $\begin{array}{c}0.0847^{*} \\
(0.0495)\end{array}$ & & & & & $\begin{array}{c}0.0253 \\
(0.0359)\end{array}$ & \\
\hline Government effectiveness & & & & $\begin{array}{l}-0.488^{* * *} \\
(0.0667)\end{array}$ & $\begin{array}{c}-0.395^{\star * *} \\
(0.0421)\end{array}$ & & & & $\begin{array}{l}-0.121^{* *} \\
(0.0600)\end{array}$ & $\begin{array}{c}-0.118^{\star \star \star} \\
(0.0450)\end{array}$ \\
\hline High minimum wage & & $\begin{array}{l}0.349^{\star * *} \\
(0.0662)\end{array}$ & $\begin{array}{l}0.324^{\star \star *} \\
(0.0621)\end{array}$ & & $\begin{array}{c}0.141^{\star *} \\
(0.0599)\end{array}$ & & $\begin{array}{l}0.0713^{*} \\
(0.0418)\end{array}$ & $\begin{array}{l}0.0755^{*} \\
(0.0399)\end{array}$ & & $\begin{array}{c}0.0595 \\
(0.0452)\end{array}$ \\
\hline High minimum wage * Government effectiveness & & & & & $\begin{array}{c}0.218^{\star} \\
(0.130)\end{array}$ & & & & & $\begin{array}{c}0.0755 \\
(0.0978)\end{array}$ \\
\hline Log GDP per capita & & & & & & $\begin{array}{l}-0.159^{* * *} \\
(0.00949)\end{array}$ & $\begin{array}{c}-0.160^{* * *} \\
(0.0106)\end{array}$ & $\begin{array}{c}-0.151^{\text {*** }}(0.0104)\end{array}$ & $\begin{array}{c}-0.138^{* * *} \\
(0.0138)\end{array}$ & $\begin{array}{c}-0.133^{\star * *} \\
(0.0148)\end{array}$ \\
\hline Constant & $\begin{array}{l}0.321^{* * *} \\
(0.0438)\end{array}$ & $\begin{array}{l}0.409^{\star \star *} \\
(0.0275)\end{array}$ & $\begin{array}{l}0.281^{\star \star *} \\
(0.0400)\end{array}$ & $\begin{array}{l}0.661^{\star * *} \\
(0.0526)\end{array}$ & $\begin{array}{l}0.646^{\star \star \star} \\
(0.0325)\end{array}$ & $\begin{array}{l}2.875^{\star * *} \\
(0.154)\end{array}$ & $\begin{array}{c}2.939^{* \star *} \\
(0.168)\end{array}$ & $\begin{array}{l}2.730^{\star \star * *} \\
(0.170)\end{array}$ & $\begin{array}{c}2.621^{* * *} \\
(0.200)\end{array}$ & $\begin{array}{c}2.589^{\star \star \star} \\
(0.216)\end{array}$ \\
\hline Observ & 108 & 110 & 108 & 105 & 107 & 107 & 108 & 107 & 104 & 105 \\
\hline R-squared & 0.144 & 0.204 & 0.320 & 0.567 & 0.571 & 0.768 & 0.750 & 0.776 & 0.784 & 0.772 \\
\hline
\end{tabular}

Source: Authors' calculations based on data from the International Labour Organization, World Bank, World Development Indicators, and World Bank, Doing Business Indicators.

Note: High minimum wage is a dummy variable taking value one if a country has a minimum wage to labor productivity ratio that exceeds the sample average. Standard errors in parentheses.

${ }^{* * *} p<0.01,{ }^{* *} p<0.05,{ }^{*} p<0.1$.

\section{LABOR MARKET FleXibiLITY AND THE SPEEd OF AdJUSTMENT OF EMPLOYMENT}

A flexible labor market is critical for the adjustment of the aggregate economy to shocks and thus for productivity growth. The economic and social costs of shocks depend on a country's ability to (i) mitigate their immediate impacts and (ii) to revert swiftly to its potential in the aftermath. The former is typically associated with the use of macroeconomic stabilization tools. The latter depends on the use of macro instruments and on the presence of microeconomic frictions that cause shocks to have protracted economic effects that amplify their welfare costs. ${ }^{2}$ Thus, understanding the factors underpinning a country's speed of adjustment to shocks is crucial to assessing its macroeconomic performance. This section expands the analysis by studying the response of employment growth to shocks that lead to deviations from equilibrium employment levels.

\footnotetext{
${ }^{1}$ The link between informality rates and de facto regulation is also studied in Finkelstein Shapiro (2015). Importantly, the results on Table 2 highlight the complex interaction between institutional quality and informality. As highlighted by Finkelstein Shapiro (2015) and Loayza et al. (2005), to the extent that they increase GDP and formal job growth, stronger institutions can lead to lower informality. This is captured by the positive coefficient of the government effectiveness proxy, which is correlated with other measures of institutional quality. On the other hand, improvements in government effectiveness can exacerbate the effects of regulation on informality, as shown by the interaction term in the table.

${ }^{2}$ Blanchard and others (2014) argue that labor institutions are critical for an efficient and equitable adjustment process. The key institutions for macro-flexibility are minimum wages and collective bargaining, while EPL and unemployment insurance are key for micro-flexibility - the ability of the economy to reallocate workers across sectors.
} 


\section{A. Macro-Flexibility and the Speed of Adjustment}

To estimate the speed of adjustment of aggregate employment to shocks, this section considers an error-correction model (ECM) within a heterogeneous panel setting following the approach proposed by Eberhardt and Presbitero (2015). The model assumes that the long-term equilibrium level of employment is related to GDP. Under this assumption, the ECM studies the response of employment growth to both shocks to GDP growth and deviations from the long-run relationship between employment and GDP. The elasticity to the latter variable is the parameter of interest throughout this section.

The methodology uses cross-sectional averages of all variables to capture unobservable variables and omitted elements of the relationship. The maximum number of lags presented in the exercise $(p=2)$ is chosen according to the "rule of thumb" in Chaudik and Pesaran (2015) for the CCE estimator to perform well in a dynamic model with weakly exogenous regressors.

The empirical specification can be summarized in equation 2 for $i=1, \ldots, N$ countries; and $t=1, \ldots, T$ time periods.

$$
\begin{aligned}
& \Delta e_{i, t}=\beta_{i} \Delta y_{i, t}+\alpha_{i}\left(e_{i, t-1}-\theta_{i} y_{i, t-1}\right)+\vartheta_{i, t} \\
& \vartheta_{i, t}=\alpha_{i}+\sum_{m=1}^{p} \lambda_{i, m} f_{m, t}+\varepsilon_{i, t}
\end{aligned}
$$

where $\Delta$ is the difference operator, $e_{i t}$ is log employment and $y_{i t}$ is log GDP. The parameter $\beta_{i}$ captures the response of employment growth in country $i$ to GDP shocks, the parameter $\theta_{i}$ is the long-run elasticity of employment to GDP, and $\alpha_{i}$ is the speed of adjustment parameter. As above, the unobserved parameters $f_{m, t}$ and $\lambda_{i, m}$ capture common factors and their loadings, respectively. The results of the heterogeneous panel ECM are presented in Table 4. The estimation uses annual data for 171 countries over the period 1990 to 2017. For comparison, the table shows the results of a standard fixed effects estimation of the error-correction model and three alternative specifications of the CCE model in (2): one that includes only contemporaneous GDP growth, one that includes lagged GDP growth and another that includes lagged employment growth and two lags of GDP growth.

As expected, employment growth is positively correlated with contemporaneous GDP growth (the coefficient for GDP growth) across specifications. It is also negatively correlated with "excess" employment (defined as employment levels above those predicted by GDP levels), evidence of reversion to the long-run employment-GDP relationship.

Importantly, a comparison between Columns 1 and 2 shows that the average speed of adjustment of the CCE model is substantially bigger than the one estimated by standard fixed effects (a factor of 10). This suggests that the omission of the common factors leads to a downward bias in the average speed of adjustment coefficient. The same is true when comparing the elasticity of employment growth to GDP growth between the two models. Changes to the lag structure of GDP and employment growth in the CCE model does not seem to affect significantly the magnitude of the estimated coefficients for the speed of adjustment parameter nor the elasticity to GDP growth (Columns 2-4).

The estimated coefficients suggest that the speed at which employment reverts to its long-run level is relatively slow on average, but there is a large degree of heterogeneity across countries. 
The average estimated speed of adjustment coefficient is -0.22 , which implies that it takes the average country approximately 3 years to close half the employment gap (the half-life). There are, however, approximately 50 percent of countries in the sample for which the speed of adjustment is higher than the average. For reference, a country located in the $75^{\text {th }}$ percentile of the distribution has a speed of adjustment of -0.41 (approximately the estimated coefficient for Nicaragua and El Salvador), which implies a half-life of 1.3 years.

Heterogeneity in the estimated speed of adjustment is also evident across income groups and regions and within them. The median country in LAC has an estimated speed of adjustment coefficient of -0.2 , which is lower than both the median advanced economy country $(-0.28)$ and emerging market country (-0.26) (Figure 3). The median value, however, masks a great degree of heterogeneity within groups. Similar results hold for group averages. Within LAC, countries in South America have a median speed of adjustment that is lower than the one observed for countries in Central America. One point to notice is that, despite differences in point estimates, differences across countries may not be statically significant. For example, there is a great degree of variation in the estimated coefficients for Chile, Brazil, Peru and Mexico, with coefficients ranging from -0.2 to 0.2 . Nevertheless, in all four cases the estimated speed of adjustment is statistically non-significant.

Table 4. Common Correlated Effect Error-Correction Model of Employment

\begin{tabular}{|c|c|c|c|c|}
\hline & \multirow{2}{*}{$\begin{array}{l}\text { Fixed Effects Estimation } \\
(1)\end{array}$} & \multicolumn{3}{|c|}{ Common Correlated Effects Estimation } \\
\hline & & $(2)$ & (3) & (4) \\
\hline Lagged log employment & $\begin{array}{l}-0.018^{* * *} \\
(0.003)\end{array}$ & $\begin{array}{c}-0.189^{* * *} \\
(0.023)\end{array}$ & $\begin{array}{c}-0.199 * * * \\
(0.027)\end{array}$ & $\begin{array}{c}-0.214^{\star \star \star} \\
(0.03)\end{array}$ \\
\hline Lagged log GDP & $\begin{array}{c}0.003 \\
(0.002)\end{array}$ & $\begin{array}{c}0.086^{\star \star \star} \\
(0.017)\end{array}$ & $\begin{array}{l}0.081^{* * *} \\
(0.019)\end{array}$ & $\begin{array}{c}0.067^{\star \star \star} \\
(0.019)\end{array}$ \\
\hline GDP growth & $\begin{array}{l}0.031^{\star \star \star} \\
(0.006)\end{array}$ & $\begin{array}{l}0.11^{\star \star *} \\
(0.019)\end{array}$ & $\begin{array}{c}0.106^{* * *} \\
(0.022)\end{array}$ & $\begin{array}{c}0.125^{\star \star \star} \\
(0.023)\end{array}$ \\
\hline GDP growth $\mathrm{t}-1$ & & & $\begin{array}{c}0.007 \\
(0.015)\end{array}$ & $\begin{array}{c}0.014 \\
(0.021)\end{array}$ \\
\hline GDP growth $\mathrm{t}-2$ & & & & $\begin{array}{c}0.01 \\
(0.016)\end{array}$ \\
\hline Employment growth $\mathrm{t}-1$ & - & & & $\begin{array}{l}0.063^{*} \\
(0.036)\end{array}$ \\
\hline Implied long-run elasticity & $\begin{array}{c}0.1535 \\
0.098\end{array}$ & $\begin{array}{c}0.4581^{* * *} \\
(0.1034)\end{array}$ & $\begin{array}{l}0.4084^{\star * *} \\
(0.1128)\end{array}$ & $\begin{array}{c}0.3141 \\
(0.1007)\end{array}$ \\
\hline Observations & 4327 & 4025 & 3993 & 3881 \\
\hline Number of countries & 171 & 171 & 170 & 164 \\
\hline
\end{tabular}

Source: Authors' calculations based on data from the International Labour Organization and World Bank, World Development Indicators. Note: Standard errors in parentheses. All Common Correlated Effects Estimation (CCE) estimations include lagged values for the crosssectional averages of the regressors. The number of lags (2) is chosen according to the "rule of thumb" proposed in Chudik and Pesaran (2015).

${ }^{* * *} p<0.01,{ }^{* *} p<0.05,{ }^{*} p<0.1$. 
Figure 3. Speed of Adjustment Coefficients

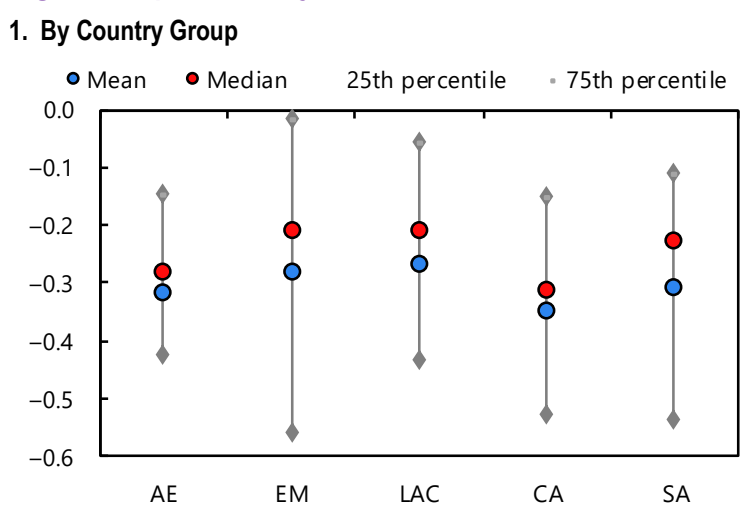

2. Selected LAC Economies

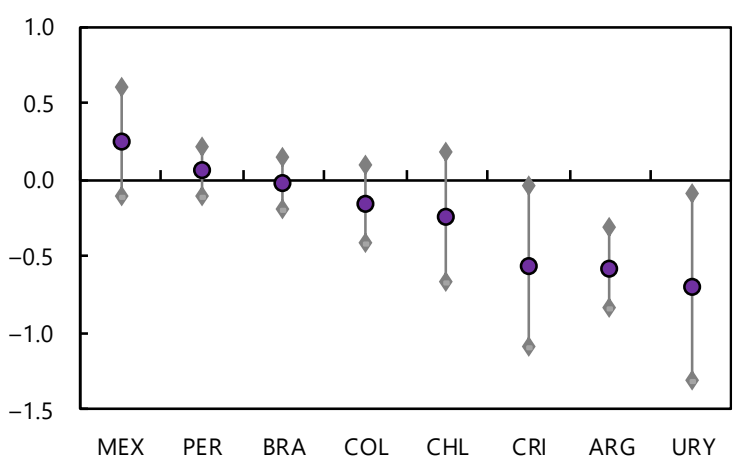

Source: Authors' calculations based on data from ILOSTAT and WDI.

Note: In panel 1 , the gray intervals are the $25-75^{\text {th }}$ percentile range for the estimated speed of adjustment coefficient for each country group. In panel 2 , the gray intervals are the 90 percent confidence interval for the estimated speed of adjustment coefficient for each country. Data labels use International Organization for Standardization (ISO) country codes. AE = advanced economies; CA = Central America; EM = emerging markets; LAC = Latin America and the Caribbean; $\mathrm{SA}=$ South America.

Differences in the coefficients of speed of adjustment of employment may be related to the characteristics of each country's labor market and the institutions and regulations governing them. A simple regression analysis shows that higher informality rates and regulations that increase job security decrease the speed of adjustment of employment (Figure 4). The estimated coefficient for informality implies that if LAC decreased its informality rate by 10 percentage points - roughly the difference between the region's average and the average for EMs in our sample of 110 countries - the region's speed of adjustment would be roughly the same as the EM average. Similarly, if the region decreased its average job security composite index by 1 (for example, by eliminating third party dismissal notification), the speed of adjustment of employment would roughly increase to the estimated average for AEs.

The estimated relationship between the speed of adjustment and informality highlights the nuanced interactions between different labor market outcomes. For example, higher informality appears to act as a buffer and attenuate the impact of shocks to GDP on unemployment (David, Lambert, and Toscani, 2019), but it also makes the adjustment process more protracted.

The results may also seem counterintuitive, as informality is often perceived to increase labor market flexibility. In fact, Finkelstein Shapiro (2014) finds that higher informality increases the speed of adjustment to shocks in the context of a DSGE model with capital and labor market frictions. These differences may be related to the fact that not all informal employment is equal. This is illustrated by Ulyssea (2018) for the case of Brazil, who classifies informal establishments into three distinct types. The first are "survival" firms, a type that is not productive enough to become formal regardless of the costs of formalization. The second type 
are "opportunistic" informal establishments, a type that takes advantage of low enforcement to save on the costs associated with formalization (and will avoid them if they can regardless of their levels). Finally, there are productive establishments that are informal but would formalize if the costs are low enough. The author finds that roughly half of informal firms in Brazil are "survival" establishments and close to 40 percent are "opportunistic".

The findings in Ulyssea (2018) are indicative of labor market segmentation, which implies that a big share of informal workers would not be employable by formal firms. The segmentation between formal and informal employment is also supported in the work of Arias et al. (2018) who find large costs of switching from an informal job to a formal job in the same industry in Mexico and Brazil. These costs are comparable to switching jobs across sectors. To explore these channels, we would have to move to samples with more disaggregated sectoral or firm-level data.

\section{B. Micro-Flexibility and the Speed of Adjustment}

Microeconomic flexibility has to do with the ability of the economy to reallocate workers across activities, facilitating the process of creative-destruction that is central to productivity growth in market economies (Caballero et al. 2013). In this section we follow these authors' approach to estimate the speed of adjustment in a micro-economic model of the labor market and study empirically the impact of labor market regulations on a country's speed of adjustment.

Their methodology allows to estimate the speed of adjustment in a micro-economic model of the labor market and study empirically the impact of labor market regulations on a country's speed of adjustment. To do so, the following equation is estimated:

$$
\Delta e_{i, t}=\alpha+\lambda_{i}\left(e_{i, t}^{*}-e_{i, t-1}\right)+\varepsilon_{i, t}=\alpha+\lambda_{i} * \operatorname{gap}_{i, t}+\varepsilon_{i, t}
$$

where $\Delta$ is the first difference operator, $e_{t}$ is the natural logarithm of employment, $e^{*}$ is the (log) equilibrium level of employment, $\left(e^{*}-e_{t-1}\right)$ is the employment gap in $\mathrm{t}-1$, and $\lambda_{i}$ is the speed of adjustment. ${ }^{3}$

To estimate equation (3) one needs to construct a proxy of the employment gap. The paper follows the methodology proposed by Caballero et al. (2013), who present a micro-founded model of labor markets and propose a two-step econometric approach. The first stage constructs an approximation of the employment gap by estimating key variables of the micro-founded model - including sectoral productivity differences. The second stage estimates equation (3) using the employment gap proxy from the first stage. Appendix B presents the technical details of the model proposed by Caballero et al. 2013 and how it links to the estimation equation (3).

The empirical exercise presented in this paper expands the work of Caballero et al. 2013 on three fronts. First, we change the period of analysis from 1980-2000 to 2000-2017. ${ }^{4}$ Throughout this period countries in Latin America experienced important changes to their macro and microeconomic policy frameworks that affected their ability to cope with shocks. The second difference is that, in addition to studying the effect of labor market regulations on a country's

\footnotetext{
${ }^{3}$ In general, the relationship between employment growth and the employment gap can be non-linear. The linear form presented in (1) can be rationalized in the context of a model with quadratic adjustment costs (see Caballero et al. 2013 and references therein).

${ }^{4}$ Prior to 1996 there is no information for the governance indicators used in the analysis.
} 
speed of adjustment, we also assess the role played by informality and policies governing worker compensation, as well as macro-stabilization policies. And third, the analysis compares the speed of adjustment obtained using data for manufacturing sectors (UNIDO) with that obtained using manufacturing, services and construction.

The key feature of the empirical exercise is to allow the speed of adjustment parameter in (3), $\lambda$, to vary with country and sectoral characteristics. These will include de jure and de facto labor market regulations (both EPLs and the minimum wage levels), the sector's labor intensity, and the country's exchange-rate regime. However, to have a reference point, the exercise starts by assuming that $\lambda_{i}$ is constant across countries. The results of the simple reference exercise are presented for two samples: one that only includes the manufacturing sectors (UNIDO sample) and one that includes manufacturing, services and construction (UNIDO + data from Timmers, de Vries and de Vries (2015) 10-sector dataset + data from the OECD's STAN dataset).

Notice that both this and the previous section estimate the employment gap using observable, albeit different, information. Moreover, the two proxies of the employment gap differ in two key dimensions. First, there is a difference in terms of sign: the employment gap used in the CCEM exercise is the difference between equilibrium employment and actual employment, which means that a positive employment gap reflects labor market slack. In contrast, a positive employment gap in the CCE estimation is a symptom of labor market tightness. For this reason, one expects the speed of adjustment coefficients from these two exercises to have the opposite sign. The choices of how to construct the employment gap in each exercise in this paper and how to present the estimated speed of adjustment coefficients are made to facilitate comparisons with previous work. The second difference between the two proxies of the employment gap is that in the CCE exercise the gap is derived from a statistical relationship between employment and GDP while in the CCEM exercise it stems from an economic model.

The results of the estimation of equation 3 point to a slower adjustment coefficient when services and construction are included. On average, manufacturing sectors close 50 percent of the employment gap in each period (Table 5, Column 1). The coefficient drops to approximately 45 percent in each period when services and construction are included (Column 2). The results are consistent with the findings of Appendix C, which estimates a CCE Error-Correction Model using less granular sectoral data and finds larger speed of adjustment estimates for industry compared to Services (and Agriculture). However, there are two concerns regarding the use of the combined dataset. First, differences in country and time coverage across datasets makes the interpretation of the results difficult. In addition, services subsectors and construction are at a higher level of aggregation compared to 2-digit manufacturing sectors presented in UNIDO. The inclusion of more aggregated sectors may attenuate the speed of adjustment coefficient. For this reason, the rest of the analysis focuses on the UNIDO dataset exclusively. 
Table 5. Microeconomic Flexibility, Informality, and Labor Market Regulations

\begin{tabular}{|c|c|c|c|c|c|c|c|c|}
\hline \multirow{3}{*}{$\begin{array}{l}\text { Dependent variable } \\
\text { Sample }\end{array}$} & \multicolumn{8}{|c|}{ Employment growth } \\
\hline & UNIDO & $\begin{array}{c}\text { UNIDO } \\
10 S+O E C D\end{array}$ & UNIDO & UNIDO & UNIDO & UNIDO & UNIDO & UNIDO \\
\hline & (1) & (2) & (3) & (4) & (5) & (6) & (7) & (8) \\
\hline Employment gap & $\begin{array}{l}0.501^{\star \star *} \\
(0.0427)\end{array}$ & $\begin{array}{l}0.459^{* * *} \\
(0.0410)\end{array}$ & $\begin{array}{l}0.502^{\star \star *} \\
(0.0405)\end{array}$ & $\begin{array}{l}0.514^{* * *} \\
(0.0467)\end{array}$ & $\begin{array}{l}0.536^{\star \star *} \\
(0.0434)\end{array}$ & $\begin{array}{l}0.525^{\star \star *} \\
(0.0438)\end{array}$ & $\begin{array}{l}0.541^{\star * *} \\
(0.0145)\end{array}$ & $\begin{array}{l}0.518^{\star \star *} \\
(0.0201)\end{array}$ \\
\hline Employment gap * LAC & & & $\begin{array}{l}-0.0255^{\star} \\
(0.0143)\end{array}$ & & & & & \\
\hline Employment gap * Informality & & & & $\begin{array}{c}-0.0596^{\star \star *} \\
(0.0216)\end{array}$ & & & & \\
\hline Employment gap * Job securty & & & & & $\begin{array}{c}-0.0374^{* * *} \\
(0.00561)\end{array}$ & $\begin{array}{l}-0.0223^{* \star *} \\
(0.00654)\end{array}$ & & \\
\hline $\begin{array}{l}\text { Employment gap * Job security } \\
\text { * High government effectiveness }\end{array}$ & & & & & & $\begin{array}{l}-0.0678^{\star * *} \\
(0.0134)\end{array}$ & & \\
\hline Employment gap * (Minimum wage/Labor productivity) & & & & & & & $\begin{array}{l}-0.131^{\star * *} \\
(0.0175)\end{array}$ & $\begin{array}{c}-0.0542^{* * *} \\
(0.0185)\end{array}$ \\
\hline Employment gap * (Minimum wage/Labor productivity) & & & & & & & & $-0.335^{\star \star \star}$ \\
\hline${ }^{*}$ High government effectiveness & & & & & & & & $(0.0532)$ \\
\hline Employment gap * High government effectiveness & & & & & & $\begin{array}{l}0.0469 * * * \\
(0.0157)\end{array}$ & & $\begin{array}{l}0.0973 \\
(0.121)\end{array}$ \\
\hline Constant & $\begin{array}{l}0.00173^{* * *} \\
(0.000611)\end{array}$ & $\begin{array}{l}0.00460 * * * \\
(0.000675)\end{array}$ & $\begin{array}{l}0.00186^{\star \star *} \\
(0.000618)\end{array}$ & $\begin{array}{c}0.000832 \\
(0.000688)\end{array}$ & $\begin{array}{l}0.00148^{* *} \\
(0.000616)\end{array}$ & $\begin{array}{l}0.00144^{\star *} \\
(0.000617)\end{array}$ & $\begin{array}{l}0.00200^{* * *} \\
(0.000604)\end{array}$ & $\begin{array}{l}0.00188^{\star * \star} \\
(0.000706)\end{array}$ \\
\hline Year-country fixed effects & YES & YES & YES & YES & YES & YES & YES & YES \\
\hline Observations & 27988 & 30895 & 27647 & 20123 & 27056 & 26694 & 27647 & 27585 \\
\hline Number of groups & 1604 & 1693 & 1586 & 1141 & 1553 & 1549 & 1586 & 1582 \\
\hline
\end{tabular}

Source: Authors' calculations based on data from the International Labour Organization, World Bank, World Development Indicators, and World Bank, Doing Business Indicators.

Note: Murphy-Topel robust standard errors in parentheses.

${ }^{* * *} p<0.01,{ }^{* *} p<0.05,{ }^{*} p<0.1$.

Turning back to the UNIDO sample, LAC countries exhibit slower speed of adjustment than other countries and this is likely related to the somewhat higher levels of informality. Column 3 shows that the speed of adjustment for the average country in LAC is approximately 2.5 percentage points lower compared to countries outside the region. As documented in the previous section, Column 4 suggests that higher informality levels are also associated to slower adjustment of employment. ${ }^{5}$

One possible explanation for LAC's relatively slow employment adjustment and for the negative impact of informality is the role played by labor market policies in shaping microeconomic flexibility. LAC has stricter EPLs compared to other countries and previous sections documented that informality is associated with stricter EPLs. As documented in Caballero et al. (2013), strict EPLs tend to hamper an economy's reaction to economic shocks. Moreover, the stiffening effect of EPLs increases as countries increase their government effectiveness and these regulations become more binding. The same applies for the minimum wage relative to labor productivity.

As in CCEM, we find that job security decreases a country's speed of adjustment to shocks (Table 5, Column 5). ${ }^{6}$ Similarly, the results suggest that high minimum wages (relative to labor productivity) erode a country's microeconomic flexibility. Both these effects are amplified when

\footnotetext{
${ }^{5}$ Appendix C suggests that the economy-wide impact of informality may be larger, given that the elasticity for industry is lower than for other sectors.

${ }^{6}$ The results in Table 4 do not appear to be driven by the omission of other variables that may be correlated with government effectiveness. For example, the inclusion of the interaction between GDP per capita and the employment gap does not change qualitatively the results. Similarly, the results are robust to the inclusion of sectoral fixed effects and sector-time fixed effects.
} 
countries have a higher ability to enforce labor market regulations (Columns 7 and 8). The findings are consistent with Chapter 3 of the October 2019 World Economic Outlook (IMF, 2019b), which finds that a major easing of labor market regulations leads to increases in employment and investment in the average country over the medium run.

To get a sense of the economic relevance of the parameters estimated above, Table 6 quantifies the implied speed of adjustment coefficient and the associated half-life ${ }^{7}$ for countries with different levels of informality, job security, relative minimum wages, and government effectiveness. Other things equal, the estimated speed of adjustment of a country with high informality ( $80^{\text {th }}$ percentile of the informality distribution) is approximately 4 percentage points lower compared to a country with low informality $\left(20^{\text {th }}\right.$ percentile of the distribution $)$. This implies that it takes the former 1.5 additional months to close the employment gap in half compared to the latter.

Turning to regulations, the results suggest that the difference in speed of adjustment between countries with low and high employment protection is 10 percentage points when government effectiveness is high. This translates into approximately 4 additional months to close the employment gap in half. The differences are relatively smaller when enforcement is weak. The effect of differences in minimum wages on the speed of adjustment appears to be even larger. The difference in the speed of adjustment parameter between countries with low and high relative minimum wages is 16 percentage points when enforcement is high. This implies six additional months to close half the employment gap and restore equilibrium in the labor market.

\section{Micro-Flexibility Heterogeneity Across Sectors}

So far, the analysis has studied the average effect of labor market regulations across sectors. However, it is plausible to assume that labor market regulations could have a heterogeneous effect across sectors. This heterogeneity could arise, for example, due to differences in the intensity of use of labor in the production process. One expects that the micro-flexibility of sectors that are more intensive in the use of labor will be more severely affected by labor regulations compared those sectors that are less reliant on labor.

To study the differential sectoral impact of labor regulations on micro-flexibility, Table 7 presents the results of a specification of the adjustment parameter that interacts labor market regulations with the labor intensity of the sector. The results confirm the differential impact of labor market regulations across sectors. The decline in micro-flexibility due to employment protection regulations is larger in labor-intensive sectors (Column 1). The results are even more striking when considering the effects of the ratio between minimum wages and labor productivity (Column 2, sixth row): high minimum wages have a major negative impact on the speed of employment adjustment in labor-intensive sectors.

\footnotetext{
${ }^{7}$ The half-life is the time (in months) it takes a country to close 50 percent of its employment gap, according to the estimated speed of adjustment. It is calculated as $12 *(\log (0.5) / \log (1$-speed of adjustment $))$.
} 
Table 6. Speed of Adjustment and Labor Market Characteristics

\begin{tabular}{|c|c|c|c|c|}
\hline & & $\begin{array}{c}\text { Estimated } \\
\text { Speed of } \\
\text { Adjustment }\end{array}$ & $\begin{array}{c}\text { Implied } \\
\text { half life } \\
\text { (in months) }\end{array}$ & $\begin{array}{c}\text { Implied growth } \\
\text { differential } \\
\text { (low-high) }\end{array}$ \\
\hline Average & & 0.50 & 12.00 & - \\
\hline LAC & & 0.48 & 12.91 & - \\
\hline \multirow{2}{*}{ Informality } & Low & 0.51 & 11.79 & \\
\hline & High & 0.47 & 13.26 & $0.17 p p$ \\
\hline \multirow{4}{*}{ Job security } & Low, High government effectiveness & 0.54 & 10.56 & \\
\hline & High, High government effectiveness & 0.43 & 14.61 & $0.47 p p$ \\
\hline & Low, Low government effectiveness & 0.52 & 11.39 & \\
\hline & High, Low government effectiveness & 0.49 & 12.32 & $0.11 p p$ \\
\hline \multirow{4}{*}{ Minimum wage/Labor productivity } & Low, High government effectiveness & 0.55 & 10.56 & \\
\hline & High, High government effectiveness & 0.39 & 16.85 & $0.74 p p$ \\
\hline & Low, Low government effectiveness & 0.51 & 11.72 & \\
\hline & High, Low government effectiveness & 0.49 & 12.48 & $0.09 p p$ \\
\hline
\end{tabular}

Source: Authors' calculations.

Note: In the case of informality, job security, and minimim wages, "Low" stands for levels at the 20th percentile of the distribution and "High" stands for levels at the 80th percentile. In the case of government effectiveness, "High" is a dummy variable taking value 1 if the estimated government effectiveness is higher than the global median. For details on implied growth differential, see Appendix A.

\section{Labor Market Flexibility and the Interaction Between Micro and Macro Policies}

As mentioned above, the adjustment of an economy following shocks depends on its macrostabilization policies and its micro-economic policies and institutions. Moreover, both types of policies could interact in ways that reinforce or erode each other's ability to facilitate the adjustment process.

With this in mind, we analyze empirically the extent to which labor market regulations interact with a country's exchange rate regime in shaping labor market adjustments. To conduct this assessment, Columns 3-5 of Table 6 present results of a parametrization of the adjustment coefficients that allows it to vary with a country's exchange rate regime, with labor market regulations and with the interaction between these two types of policies.

The results suggest that more flexible exchange rate regimes are associated with more flexible labor markets and faster adjustment in employment levels (Column 3). This is evidence of the power of flexible exchange rates as a stabilization tool. However, the effectiveness of the flexibility of a country's exchange rate regime as an adjustment tool appears to be linked to the specific source of labor market rigidities. In the case of regulations on quantities (EPLs), evidence suggests that more stringent EPLs lower the power of flexible exchange rate regimes as stabilization tools, albeit the effect is not statistically significant (Column 4). Minimum wages, by contrast, do not seem to erode the effectiveness of flexible exchange rates. On the contrary, exchange rate flexibility appears to be more effective in facilitating adjustments when the minimum wage is more binding (Column 5).

\section{Asymmetric Effects of Labor Market Regulations}

The baseline exercise assumes that the effects of labor market regulations are symmetric along the business-cycle. However, as shown in Caballero et al. (2013), this may not be the case. Thus, the empirical specification presented next allows for the effect of labor market regulations to vary depending on whether employment is above or below its equilibrium level (the gap is positive or negative). As in Caballero et al. (2013), this is implemented by constructing a dummy 
variable taking the value 1 if the employment gap is negative and zero otherwise. Having calculated this dummy, the exercise interacts the employment gap with the specific labor market regulation and the dummy.

Table 7. Sectoral Heterogeneity, Interactions with Macro policies, and Asymmetric Responses

\begin{tabular}{|c|c|c|c|c|c|c|c|}
\hline \multirow[t]{2}{*}{ Dependent variable } & \multicolumn{7}{|c|}{ Employment growth } \\
\hline & (1) & (2) & (3) & (4) & (5) & (6) & (7) \\
\hline Employment gap & $\begin{array}{l}0.478^{\star * *} \\
(0.0484)\end{array}$ & $\begin{array}{l}0.465^{\star \star \star} \\
(0.0476)\end{array}$ & $\begin{array}{l}0.486^{\star \star \star} \\
(0.0437)\end{array}$ & $\begin{array}{l}0.516^{\star \star *} \\
(0.0445)\end{array}$ & $\begin{array}{l}0.541^{\star * \star} \\
(0.0456)\end{array}$ & $\begin{array}{l}0.508^{\star \star \star} \\
(0.0447)\end{array}$ & $\begin{array}{l}0.548^{\star \star \star} \\
(0.0478)\end{array}$ \\
\hline Employment gap * (Minimum wage/Labor productivity) & & $\begin{array}{l}-0.0106 \\
(0.0403)\end{array}$ & & & $\begin{array}{l}-0.177^{\star * *} \\
(0.0182)\end{array}$ & & $\begin{array}{r}-0.172^{* * *} \\
(0.0295)\end{array}$ \\
\hline Employment gap * Job security & $\begin{array}{l}-0.0167 \\
(0.0149)\end{array}$ & & & $\begin{array}{l}-0.0316^{* * *} \\
(0.00646)\end{array}$ & & $\begin{array}{l}-0.0178^{\star} \\
(0.00971)\end{array}$ & \\
\hline Employment gap * Labor intensity & $\begin{array}{l}0.485^{\star \star \star} \\
(0.160)\end{array}$ & $\begin{array}{l}0.625^{\star \star \star} \\
(0.186)\end{array}$ & & & & & \\
\hline $\begin{array}{l}\text { Employment gap * Job Security } \\
\text { * Labor intensity }\end{array}$ & $\begin{array}{l}-0.174 \\
(0.115)\end{array}$ & & & & & & \\
\hline $\begin{array}{l}\text { Employment gap * (Minimum wage/Labor productivity) } \\
\text { * Labor intensity }\end{array}$ & & $\begin{array}{c}-0.997^{* * \star} \\
(0.320)\end{array}$ & & & & & \\
\hline Employment gap * Exchange Rate Flexibility & & & $\begin{array}{l}0.0802^{\star * \star} \\
(0.0117)\end{array}$ & $\begin{array}{l}0.0889^{\star * *} \\
(0.0201)\end{array}$ & $\begin{array}{c}0.0171 \\
(0.0317)\end{array}$ & & \\
\hline $\begin{array}{l}\text { Employment gap * Job security } \\
\text { *Exchange Rate Flexibility }\end{array}$ & & & & $\begin{array}{l}-0.0107 \\
(0.0149)\end{array}$ & & & \\
\hline $\begin{array}{l}\text { Employment gap * (Minimum wage/Labor productivity) } \\
\text { * Exchange Rate Flexibility }\end{array}$ & & & & & $\begin{array}{l}0.199 * \star \star \\
(0.0671)\end{array}$ & & \\
\hline Employment gap * Negative gap dummy & & & & & & $\begin{array}{l}0.0690^{\star * *} \\
(0.0212)\end{array}$ & $\begin{array}{l}-0.00484 \\
(0.0200)\end{array}$ \\
\hline $\begin{array}{l}\text { Employment gap * Job security } \\
* \text { Negative gap dummy }\end{array}$ & & & & & & $\begin{array}{l}-0.0414^{\star *} \\
(0.0166)\end{array}$ & \\
\hline $\begin{array}{l}\text { Employment gap * (Minimum wage/Labor productivity) } \\
\text { * Negative gap dummy }\end{array}$ & & & & & & & $\begin{array}{l}0.0927^{*} \\
(0.0484)\end{array}$ \\
\hline Negative gap dummy & & & & & & $\begin{array}{c}0.00286 \\
(0.00185)\end{array}$ & $\begin{array}{r}0.00287 \\
(0.00183)\end{array}$ \\
\hline Constant & $\begin{array}{l}0.00157^{* *} \\
(0.000616)\end{array}$ & $\begin{array}{l}0.00210^{\star * *} \\
(0.000607)\end{array}$ & $\begin{array}{l}0.00192^{* * *} \\
(0.000639)\end{array}$ & $\begin{array}{l}0.00155^{\star *} \\
(0.000635)\end{array}$ & $\begin{array}{l}0.00208^{\star \star *} \\
(0.000631)\end{array}$ & $\begin{array}{c}0.00159 \\
(0.00127)\end{array}$ & $\begin{array}{r}0.00198 \\
(0.00124)\end{array}$ \\
\hline Year-country fixed effects & YES & YES & YES & YES & YES & YES & YES \\
\hline Observations & 27052 & 27643 & 26011 & 25439 & 26011 & 27056 & 27647 \\
\hline Number of groups & 1553 & 1586 & 1491 & 1459 & 1491 & 1553 & 1586 \\
\hline
\end{tabular}

Source: Authors' calculations based on data from the International Labour Organization, World Bank, World Development Indicators, and World Bank, Doing Business Indicators.

Note: Murphy-Topel robust standard errors in parentheses.

${ }^{* * *} p<0.01,{ }^{* *} p<0.05,{ }^{*} p<0.1$.

The results of the exercise, presented in Columns 6 and 7 of Table 6, provide evidence of asymmetric effects of labor market regulations on employment dynamics. EPLs slow the adjustment process especially when employment is above its equilibrium level (the gap is negative). This suggests that EPLs have a larger impact on the (net) job destruction margin. By contrast, a more binding minimum wage affects more the adjustment process when employment is below its equilibrium level (positive gap). Thus, more binding minimum wages affect disproportionately the (net) job creation margin. 


\section{LABOR MARKET REgULATION AND GROWTH}

By slowing a country's labor market responsiveness to shocks, excessively stringent labor regulations could lower productivity growth. ${ }^{8}$ For example, labor market regulations hamper the reallocation of factors of production across sectors and firms. Through labor market regulations, one could thus expect to find a link between a country's medium-term growth and its microeconomic flexibility. In fact, a simple plot of GDP per worker growth and a country's speed of adjustment shows a positive correlation between the two (Figure 5). Similarly, a simple back-of-the envelope calculation, like the one presented in Caballero et al. (2013), shows that changes in employment protection regulations that move a country from the $80^{\text {th }}$ percentile of the speed of adjustment distribution to the $20^{\text {th }}$ percentile is associated with an increase in medium-term labor productivity growth of 0.5 percentage points (pp) per annum (Table 5, last column). Similarly, changing the minimum wage from the $80^{\text {th }}$ to the $20^{\text {th }}$ percentile of the distribution when government effectiveness is high can increase growth by approximately 0.75 pp per annum.

To further study the effects of labor market regulations on growth, the paper follows a difference-in-difference approach similar to the one proposed by Rajan and Zingales (1998). In particular, the prior is that labor market regulations affect disproportionately sectors that are more labor-intensive because of global technological factors. ${ }^{9}$ With this idea in mind, we estimate the following equation:

$$
g_{i j t}=\beta \alpha_{j t-1}+\gamma \alpha_{j t-1} * r e g_{i}+\theta X_{i j t}+\varepsilon_{i j t}
$$

where $g_{i j t}$ is the growth of sector j's labor productivity, in country i, at time t, $\alpha_{j t}$ is the labor share in value added of sector $\mathrm{j}$ at time $\mathrm{t}$, which we calculate as the median labor share across countries, $r e g_{i}$ is the either the proxy for employment protection legislations or the minimum wage over labor productivity ratio, and $X_{i j t}$ are additional controls (which include the sector's capital share, the sector's initial share in total value added, and country-year fixed effects).

The goal of using the DID approach is to minimize the incidence of the potential endogeneity between growth and labor market regulations on the estimated parameters. Endogeneity may be a

\footnotetext{
${ }^{8}$ The literature has identified several channels through which employment protection can affect growth. For example, Autor, Kerr, and Kugler (2007) find evidence that stricter employment protection in the US is associated with reduced employment flows, lower firm entry rates, and lower total factor productivity (TFP). Strict EP can also lower FDI inflows, decreasing the potential for knowledge transfers and the growth effects associated with the presence of foreign firms (Javorcik and Spatareanu, 2005).

${ }^{9}$ The underlying assumption is that, although there may be differences across countries in the use of production technologies, the ranking of sectors in terms of their labor intensity will be relatively similar across countries.
} 
concern if, for example, one expects a country experiencing low growth may introduce stiffer employment protection laws to reduce layoffs.

As conjectured, the results in Table 8 suggest that the growth-hampering effects of labor market regulations are larger in labor-intensive sectors. Higher EPL and minimum wages lower labor productivity growth. This result is robust to the inclusion of the initial share of the sector in total value added, the capital share of the sector, and fixed effects that capture time-varying country and sectoral characteristics. Note that the effect of EPL does not seem to consistently affect capital-intensive sectors.

Table 8. Labor Market Regulations and Labor Productivity Growth

\begin{tabular}{|c|c|c|c|c|c|c|}
\hline \multirow[t]{2}{*}{ Dependent variable } & \multicolumn{6}{|c|}{ Labor productivity growth } \\
\hline & $(1)$ & $(2)$ & $(3)$ & $(4)$ & $(5)$ & (6) \\
\hline Sector's share in country's total value added, $t-1$ & $\begin{array}{c}-0.156^{\star * *} \\
(0.0174)\end{array}$ & $\begin{array}{c}-0.175^{* * *} \\
(0.0180)\end{array}$ & $\begin{array}{c}-0.176^{* * *} \\
(0.0183)\end{array}$ & $\begin{array}{c}-0.174^{\star * *} \\
(0.0180)\end{array}$ & $\begin{array}{c}-0.154^{* * *} \\
(0.0178)\end{array}$ & $\begin{array}{c}-0.153^{* * *} \\
(0.0174)\end{array}$ \\
\hline Sectoral labor share, $t-1$ & & $\begin{array}{c}-0.132^{\star * *} \\
(0.0327)\end{array}$ & $\begin{array}{l}-0.0466 \\
(0.0519)\end{array}$ & $\begin{array}{l}-0.0366 \\
(0.0546)\end{array}$ & & \\
\hline Country's job security * Sectoral labor share, $t-1$ & & & $\begin{array}{c}-0.0884^{* *} \\
(0.0423)\end{array}$ & & & \\
\hline Country's rel. minimum wage * Sectoral labor share, $t-1$ & & & & $\begin{array}{c}-0.267^{* *} \\
(0.122)\end{array}$ & & \\
\hline Country's job security * Sectoral capital share, $t-1$ & & & & & $\begin{array}{l}0.0249 \\
(0.119)\end{array}$ & \\
\hline Country's rel. minimum wage * Sectoral capital share, $t-1$ & & & & & & $\begin{array}{c}0.00348 \\
(0.377)\end{array}$ \\
\hline Constant & $\begin{array}{l}0.0455^{\star \star *} \\
(0.00159)\end{array}$ & $\begin{array}{l}0.0628^{\star \star \star} \\
(0.00459)\end{array}$ & $\begin{array}{l}0.0629^{\star \star *} \\
(0.00462)\end{array}$ & $\begin{array}{l}0.0624^{\star \star \star} \\
(0.00459)\end{array}$ & $\begin{array}{l}0.0568^{\star \star \star} \\
(0.00359)\end{array}$ & $\begin{array}{l}0.0564^{\star \star \star} \\
(0.00350)\end{array}$ \\
\hline Country-Year Fixed Effects & YES & YES & YES & YES & YES & YES \\
\hline Sectoral Capital Share control & NO & NO & NO & NO & YES & YES \\
\hline Observations & 26,552 & 26,539 & 25,977 & 26,539 & 25,856 & 26,418 \\
\hline$\underline{\text { R-squared }}$ & 0.196 & 0.197 & 0.199 & 0.197 & 0.199 & 0.197 \\
\hline
\end{tabular}

\section{CONCLUSION ANd Policy Implications}

Informality and labor market regulations play a crucial role in the dynamics of labor markets in Latin America. Previous work provides evidence that informality dampens the effects of macroeconomic shocks on employment providing a buffer for low-skilled workers, especially in downturns. At the same time this paper shows that informality makes the employment adjustment to shocks more sluggish. Informality is linked to strict labor market regulations (i.e., certain dimensions of stricter employment protection legislation increase informality), which also affect labor market flexibility. Moreover, the institutional factors that are correlated with informality appear to lower the speed of adjustment of employment and hamper growth.

The paper shows that different regulations may be more binding in different phases of the cycle. Employment protection regulations appear to affect more the (net) destruction margin while minimum wages affect the (net) job creation margin. The results also provide evidence that EPL undermine the employment benefits of macro-stabilization tools, like exchange rate flexibility. 
The paper also finds that high minimum wages relative to labor productivity increase informality, lowers the speed of adjustment to shocks, and hampers growth. As suggested in IMF (2019b), embarking on structural reforms that increase labor productivity would be the best way to address this determinant of informality.

Should we reduce informality and if so how? The reduction of informality and the labor market regulations and taxes that are its main determinants involves a number of complex trade-off, some of which were not included in this paper (including equity and other considerations, see Duval and Loungani (2019) and IMF (2019a)). The paper highlights two important trade-offs when designing labor market regulations. The first trade-off is between employment protection and and labor market dynamism and the quality of jobs. As discussed, stringent labor market regulations may limit employment losses in downturns, but this may come at the expense of an increase in informal employment, which is typically lower paying, and a sluggish recovery.

This trade-off may be partly resolved by complementing less-stringent labor market legislation with a modern safety net that includes a robust system of unemployment insurance and other benefits. The second trade-off regards the potential impact of labor market legislation on the effectiveness of macro-stabilization tools including, but not limited to, a flexible-exchange rate arrangement. The design of a set of labor market regulations that takes into account the heterogeneous effectiveness of different policy instruments over the business cycle and its interactions with macro-stabilization policies could improve these trade-offs. Examples would be severance payments or minimum wage adjustments that are contingent on the state of the business cycle. 


\section{REFERENCES}

Arias, J. Artuc, E., Lederman, D., and Rojas, D., 2018. "Trade, informal employment and labor adjustment costs," Journal of Development Economics, vol. 133(C): 396-414.

Autor, D., W. Kerr, and A. Kugler, 2007. "Does Employment Protection Reduce Productivity? Evidence from the U.S.," The Economic Journal, vol. 117: F189-F217.

Blanchard, O., Jaumotte, F., Loungani, P., 2014. "Labor market policies and IMF advice in advanced economies during the Great Recession," IZA Journal of Labor Policy, vol. 3(1), pages 1-23, December.

Botero, J., S. Djankov, R. LaPorta, F. López-de-Silanes, and A. Shleifer, 2004. "The Regulation of Labor." Quarterly Journal of Economics vol. 119 (4): 1339-1382.

Caballero, R. K. Cowan, E. Engel, and A. Micco, 2013. "Effective Labor Regulation and Microeconomic Flexibility," Journal of Development Economics, Vol. 101 (2013) 92-104.

Chudik, A. and Pesaran, M.H., 2015. "Common correlated effects estimation of heterogeneous dynamic panel data models with weakly exogenous regressors," Journal of Econometrics, vol. 188 (2): 393-420.

David, A., F. Lambert and F. Toscani, 2019. "More Work to Do? Taking Stock of Latin American Labor Markets" IMF Working Paper WP/19/55.

Duval, R. and P. Loungani (2019) "Designing Labor Market Institutions in Emerging and Frontier Economies: Evidence and IMF Advice" IMF Staff Discussion Note 19/04

Eberhardt, M., and Presbitero, A., 2015. "Public Debt and Growth: Heterogeneity and NonLinearity," Journal of International Economics, Vol. 97 (1), Pages 45-58.

Finkelstein Shapiro, A., 2014. "Self-Employment and Business Cycle Persistence: Does the Composition of Employment Matter for Economic Recoveries?" Journal of Economic Dynamics and Control, vol. 46: 200-218

Finkelstein Shapiro, A., 2015. Institutions, Informal Labor Markets, and Business Cycle Volatility," Economía, vol. 16 (1): 77-112

Gali, J., and T. Monacelli, 2016. "Understanding the Gains of Wage Flexibility: The Exchange Rate Connection," American Economic Review, vol. 106 (12): 3829-62.

ILO, 2018. "Women and Men in the Informal Economy: A Statistical Picture" $3^{\text {rd }}$ Edition International Labour Office, Geneva.

Ilzetzki, E., C. Reinhart, and K. Rogoff, 2019. "Exchange Arrangements Entering the 21st Century: Which Anchor Will Hold?” Quarterly Journal of Economics 134: 599-646.

International Monetary Fund (IMF), 2019a. Regional Economic Outlook: Western Hemisphere (Washington, October).

International Monetary Fund (IMF), 2019b. World Economic Outlook (Washington, October).

Javorcik, B. and M. Spatareanu, 2005. "Do Foreign Investors care about labor market regulations?" Review of World Economics, vol. 141(3): 375-403. 
Kapetanios, G., Pesaran, M.H. and Yamagata, T., 2011. "Panels with Nonstationary Multifactor Error Structures" Journal of Econometrics, vol. 160: 326-348.

Kaufmann, D., A. Kraay, and M. Mastruzzi, 2010. "The Worldwide Governance Indicators: Methodology and Analytical Issues," Policy Research working paper WPS 5430. World Bank.

Kugler, A., 2019. "Impacts of Labor Market Institutions and Demographic Factors on Labor Markets in Latin America" IMF Working Paper WP/19/155.

Lambert, F. and Toscani, F., 2018. "Labor Market Dynamics in Latin America," REO: Background Papers, October 2018.

La Porta, R. and Shleifer, A., 2014. "Informality and Development." Journal of Economic Perspectives, vol. 28 (3): 109-26.

Loayza, N. V., 2018. "Informality : Why Is It So Widespread and How Can It Be Reduced?," Research and Policy Briefs 133110, The World Bank.

Loayza, N. V., Oviedo, A. M., and Serven, L., 2005. "The impact of regulation on growth and informality - cross-country evidence," Policy Research Working Paper Series 3623, The World Bank.

Loayza, N. V. and Rigolini, J., 2011. "Informal Employment: Safety Net or Growth Engine?," World Development, Elsevier, vol. 39 (9), pages 1503-1515, September.

Perry, G. E.; Maloney, W. F.; Arias, O. S.; Fajnzylber, P., Mason, A. D.; and SaavedraChanduvi, J., 2007. Informality: Exit and Exclusion. Latin American and Caribbean Studies. Washington, DC: World Bank.

Pesaran, M. H., 2006. "Estimation and Inference in Large Heterogeneous Panels with Multifactor Error Structure'". Econometrica, vol. 64: 967-1012.

Rajan, R. and Zingales, L., 1998. "Financial Dependence and Growth," The American Economic Review, Vol. 88 (3): 559-586.

Timmer, M. P., de Vries, G. J., \& de Vries, K. (2015). "Patterns of Structural Change in Developing Countries.” In J. Weiss, \& M. Tribe (Eds.), Routledge Handbook of Industry and Development. (pp. 65-83). Routledge.

Ulyssea, G., 2010. "Regulation of Entry, Labor Market Institutions and the Informal Sector," Journal of Development Economics, Vol. 91 (1): 87-99.

Ulyssea, G., 2018. "Firms, Informality and Development: Theory and Evidence from Brazil," American Economic Review, Vol. 108 (8): 2015-2047.

World Economic Forum, 2018. "The Global Competitiveness Report 2017-18”.

World Bank. 2019. Global Economic Prospects, January 2019: Darkening Skies. Washington, DC: World Bank. 


\section{APPENDiX A. DATA Sources AND Definitions For SELECTED VARIABLES}

\begin{tabular}{|c|c|c|c|c|}
\hline Variable & Definition & Coverage & Source & Usage \\
\hline Real GDP growth & $\begin{array}{l}\text { Change in log of real GDP (in } \\
\% \text { ) }\end{array}$ & $\begin{array}{l}178 \text { countries } \\
1990-2017\end{array}$ & IMF WEO & $\begin{array}{l}\text { Sections III } \\
\text { and IV }\end{array}$ \\
\hline Total employment & $\begin{array}{l}\text { Share of employment to } \\
\text { population } 15+(\text { in } \%)\end{array}$ & $\begin{array}{l}140 \text { countries } \\
1990-2017\end{array}$ & World Bank WDI & Section IV \\
\hline $\begin{array}{l}\text { Informal } \\
\text { employment ILO }\end{array}$ & $\begin{array}{l}\text { Share of informal employment } \\
\text { on total non-agricultural } \\
\text { employment (in \%). }\end{array}$ & $\begin{array}{l}119 \text { countries } \\
2016\end{array}$ & ILO (2018) & $\begin{array}{l}\text { Sections III } \\
\text { and IV }\end{array}$ \\
\hline $\begin{array}{l}\text { Informal } \\
\text { employment IDB }\end{array}$ & $\begin{array}{l}\text { Share of total active workers } \\
\text { that do not contribute to social } \\
\text { security (in \%). }\end{array}$ & $\begin{array}{l}17 \mathrm{LAC} \\
\text { countries } \\
1990-2017\end{array}$ & IDB SIMS & Section III \\
\hline $\begin{array}{l}\text { Informal } \\
\text { employment WB }\end{array}$ & $\begin{array}{l}\text { Share of self-employed } \\
\text { workers (in \%) }\end{array}$ & $\begin{array}{l}142 \text { countries } \\
1991-2017\end{array}$ & World Bank WDI & Section III \\
\hline $\begin{array}{l}\text { Minimum wage } \\
\text { ratio }\end{array}$ & $\begin{array}{l}\text { Ratio between the national } \\
\text { minimum wage and GDP per } \\
\text { worker (labor productivity). }\end{array}$ & $\begin{array}{l}188 \text { countries } \\
2014-2018\end{array}$ & $\begin{array}{l}\text { Doing Business } \\
\text { indicators }\end{array}$ & $\begin{array}{l}\text { Sections III } \\
\text { and IV }\end{array}$ \\
\hline Redundancy costs & $\begin{array}{l}\text { Dismissal costs in weeks of } \\
\text { salary. }\end{array}$ & $\begin{array}{l}189 \text { countries } \\
2014-2018\end{array}$ & $\begin{array}{l}\text { Doing Business } \\
\text { indicators }\end{array}$ & Section III \\
\hline $\begin{array}{l}\text { Government } \\
\text { effectiveness }\end{array}$ & $\begin{array}{l}\text { Dummy variable taking value } \\
\text { one if a country has a } \\
\text { government effectiveness } \\
\text { estimate in } 1996 \text { above the } \\
\text { global median in that year. }\end{array}$ & $\begin{array}{l}214 \text { countries } \\
1996\end{array}$ & $\begin{array}{l}\text { Kaufmann, Kraay, and } \\
\text { Mastruzzi (2010) }\end{array}$ & $\begin{array}{l}\text { Sections III } \\
\text { and IV }\end{array}$ \\
\hline $\begin{array}{l}\text { Exchange rate } \\
\text { flexibility }\end{array}$ & $\begin{array}{l}\text { Dummy variable taking value } \\
1 \text { (flexible) if the IRR index } \\
\text { takes values } 3 \text { and } 4 \text {, and zero } \\
\text { (non-flexible) if it takes } \\
\text { values } 1 \text { and } 2 \text {. }\end{array}$ & $\begin{array}{l}194 \text { countries } \\
1990-2016\end{array}$ & $\begin{array}{l}\text { Ilzetzki, Reinhart and } \\
\text { Rogoff (2019) }\end{array}$ & Section IV \\
\hline $\begin{array}{l}\text { Job security } \\
\text { indicator }\end{array}$ & $\begin{array}{l}\text { Index constructed following } \\
\text { Botero et al. (2004), } \\
\text { normalized to take a value } \\
\text { between } 0 \text { and } 1 .\end{array}$ & $\begin{array}{l}186 \text { countries } \\
\text { Average for } \\
2014-2018\end{array}$ & $\begin{array}{l}\text { Authors calculations } \\
\text { based on Doing } \\
\text { Business indicators }\end{array}$ & $\begin{array}{l}\text { Sections III } \\
\text { and IV }\end{array}$ \\
\hline $\begin{array}{l}\text { Employment, } \\
\text { output, and wages } \\
\text { by sector }\end{array}$ & Estimates by sector. & $\begin{array}{l}173 \text { countries } \\
1963-2017\end{array}$ & $\begin{array}{l}\text { INDSTAT and STAN } \\
\text { databases. }\end{array}$ & Section IV \\
\hline $\begin{array}{l}\text { Employment and } \\
\text { value-added for } \\
\text { construction and } \\
\text { services sectors }\end{array}$ & $\begin{array}{l}\text { Share of sectoral value added } \\
\text { in total value added. }\end{array}$ & $\begin{array}{l}40 \text { countries } \\
2000-2010\end{array}$ & $\begin{array}{l}\text { Timmer, de Vries and } \\
\text { de Vries (2015) }\end{array}$ & Section IV \\
\hline
\end{tabular}




\section{Appendix B. Caballero, Cowan, Engel and Micco (2013) Methodology}

Assume a sector's representative firm faces the following isoelastic demand and has access to a Cobb-Douglass production function in labor and hours per worker:

$$
\begin{aligned}
& y=a+\alpha e+\beta h \\
& p=d-\frac{1}{\eta} y
\end{aligned}
$$

where variables (in lower case) are expressed in logs. Firms are competitive in the labor market but pay wages that increase with hours worked according to a wage schedule $w(h)$, with $w$ ' and $w$ ' strictly positive. This simple framework implies that the following equilibrium equation holds:

$$
\bar{e}-e=\frac{\phi}{1-\alpha \gamma}(v-\bar{w})
$$

with $\phi=\frac{\mu-\beta \gamma}{\mu}, \mu=1+\frac{W^{\prime \prime}(\widehat{H}) \widehat{H}}{W^{\prime}(\widehat{H})}, \gamma=\frac{\eta-1}{\eta}$, and $v=y-e$.

The employment gap $(\hat{e}-e)$ presented above is the difference between employment and the firm's employment target. To introduce employment dynamics, Caballero et al. (2013) assume that the combination of supply and demand shocks $(d+\gamma a)$ follows a random walk. In that case, employment potential in country $i$, sector $j$, at time $t\left(e_{i j t}^{*}\right)$ is equal to the static equilibrium $\left(\bar{e}_{i j t}\right)$ plus a constant equal to the random walk drift. Allowing for a country-specific stochastic drift and for sector-specific differences in $\alpha$ and $\gamma$, leads to:

$$
e_{i j t}^{*}-e_{i j t-1}=\frac{\phi}{1-\alpha_{j} \gamma_{j}}\left(v_{i j t}-w_{i j t}^{0}\right)+\Delta e_{i j t}+\delta_{c t}=g a p_{i j t}+\delta_{c t}
$$

To estimate (A1), we proceed in two steps. First, taking first difference we can write the employment equation as:

$$
\Delta e_{i j t}=-\frac{\phi}{1-\alpha_{j} \gamma_{j}}\left(\Delta v_{i j t}-\Delta w_{i j t}^{0}\right)+\Delta e_{i j t}^{*}-\Delta \delta_{c t}=-\phi z_{i j t}+\kappa_{c t}+\varepsilon_{i j t}
$$

To estimation of the parameter $\phi$ is achieved by constructing the variable $z_{i j t}=\frac{\left(\Delta v_{i j t}-\Delta w_{i j t}^{0}\right)}{1-\alpha_{j} \gamma_{j}}$. To do so, $\alpha_{j} \gamma_{j}$ is approximated to be the median labor share for the sector. In the case of manufacturing, this is taken directly from the UNIDO data. For services and construction, the median labor share is built from the OECD STAN dataset. Log labor productivity $(v)$ is constructed as the log of output per worker. $w_{i j t}^{0}$ with is proxied with the average labor productivity across countries. In estimating $\phi, \Delta v_{i j t}-\Delta v_{. j t}^{0}$ is instrumented with $\Delta w_{i j t-1}-$ $\Delta w_{. j t}^{0}$.

Having estimated $\phi$, the employment gap is constructed using equation A1 and the adjustment parameter from equation 1. Importantly, because a two-step procedure is used, the MurphyTopel standard errors are constructed in the second stage, which takes into account the fact that 
$\phi$ is estimated with error. When calculating the employment gap, lagged differences between sectoral labor productivity and average productivity to account are subtracted for systematic productivity differences across sectors within countries.

Beyond its implications for employment adjustment, the model presented in Caballero et al. 2013 can be used to study the link between microeconomic flexibility and growth. More specifically, using a simple AK growth model and the microeconomic structure described above, the authors show that the difference in long-term growth between two countries that only differ in their speed of adjustment coefficient $\left(\lambda_{i}\right.$, with $\left.\lambda_{2}>\lambda_{1}\right)$ can be approximated by the following equation:

$$
g_{2}-g_{1}=\left(g_{1}-\delta\right)\left[\frac{1}{\lambda_{1}}-\frac{1}{\lambda_{2}}\right] \varepsilon
$$

Where $\delta$ is the rate of depreciation of capital and $\varepsilon$ is a constant that depends on the labor share, the volatility of productivity, and the demand elasticity. The results presented in the paper take the values used by CCEM to compute the values in Table 5. 


\section{Appendix C. Error-Correction Model Results at the Sectoral Level}

This section documents the results of the estimation of a Common Correlated Effect ErrorCorrection Model described in equation 2 in Section II for three broad sectors (agriculture, industry and services). The results, presented in Appendix Figure C.1, panel 1, show that there are large differences in the speed of adjustment across sectors. Industry has the highest average estimated coefficient of the speed of adjustment parameter and services has the lowest average estimated coefficient. Interestingly, there are also noticeable differences in the correlation between informality at the country level and the estimated sectoral speed of adjustment parameters. Informality appears to reduce the speed of adjustment parameter for services and agriculture but not for industry.

\section{Appendix Figure C.1. Common Correlated Effect Error-Correction Model by Sector}

1. Speed of Adjustment Coefficients

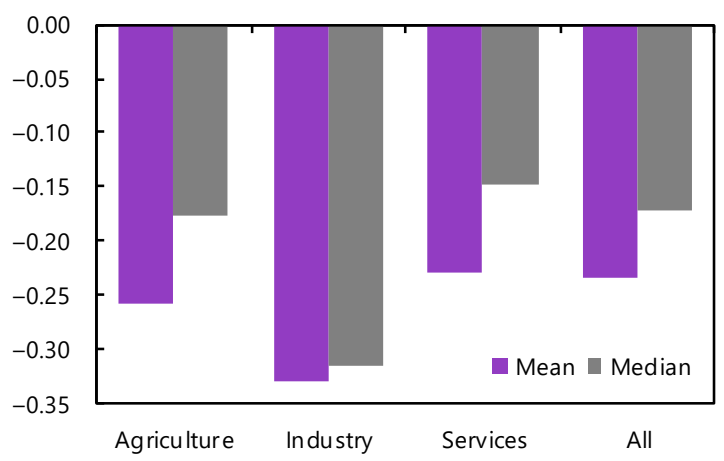

2. Elasticity of Speed of Adjustment Coefficient with Respect to (Log) Informality

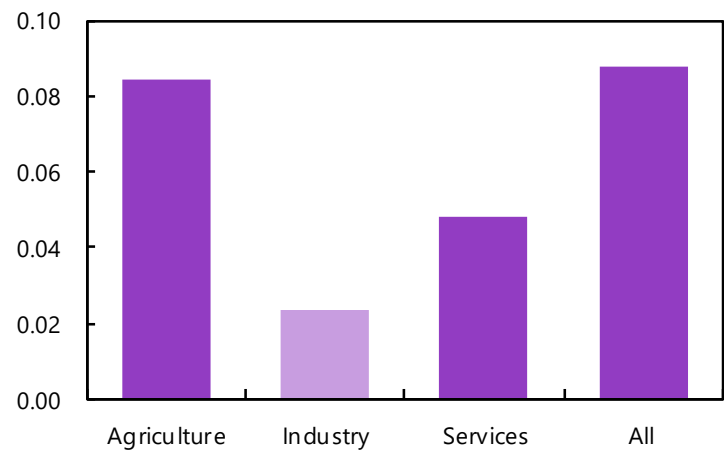

Source: Authors' calculations based on data from World Bank, World Development Indicators. Note: Solid bars are significant at the 95 percent confidence level. Light purple bars are not significant. 